MALCOLM BARBER

UNIVERSITY OF READING

\title{
Nowe spojrzenie na proces templariuszy ${ }^{1}$
}

„Organizacja uważana za jedną $z$ najdumniejszych, najbogatszych i najznaczniejszych w Europie zniknęła $z$ mapy Europy właściwie bez oporu. Nie będzie nadużyciem stwierdzenie, że pomysł jej zniszczenia nie mógł powstać sam $z$ siebie, lecz $z$ przyczyn, które w procesie inkwizycyjnym wykorzystywano bez cienia skrupułów, a gwałt ów okrywano płaszczem prawa. Jeśli zajmowałem się tą tragedia nazbyt długo, skruszony przyznaję, że powodowała mna potrzeba przedstawienia bezradności ofiary, której wysoka pozycja była bez znaczenia wobec fatalnego zarzutu herezji, wysuniętego przez przedstawicieli inkwizycji” 2 .

Tymi słowami Henry Charles Lea, amerykański badacz inkwizycji, podsumowal swoje badania w trzecim tomie opublikowanej w roku 1889 książki dotyczącej tej problematyki. „Żadne opracowanie poświęcone europejskiemu średniowieczu, a napisane przed 1895 r., nie jest warte lektury"3 - stwierdził niegdyś Norman Cantor, jednakże argumenty przytoczone przez H.Ch. Leę na niewinność templariuszy wciaż mają doniosłe znaczenie. Dwór francuski przypisywał członkom zakonu, że nie byli gotowi umierać za wiarę, acz nie znaleziono nigdy konkretnego i wiarygodnego dowodu na uprawianie przez nich bałwochwalstwa ani nie udowodniono żadnego innego przewinienia, poza wykorzystaniem świadectw wymuszonych na torturach - i tylko to było podstawą orzeczenia o winie

1 Artykuł jest pisemna forma wykładu, jaki autor miał zaprezentować $13 \mathrm{X}$ 2015 r. w Instytucie Historii Uniwersytetu Łódzkiego, ale z przyczyn zdrowotnych odwołał przyjazd.

2 H.Ch. Le a, A history of the Inquisition in the Middle Ages, t. III, New York 1889, s. 334.

${ }^{3}$ N.F. C a n tro, Inventing the Middle Ages. The Lives, Works, and Ideas of the Great Medievalists of the Twentieth Century, New York 1991, s. 44. 
zakonu. „Jeśli uznamy prawdziwość dowodów przeciwko templariuszom - pisał H.Ch. Lea - nie możemy ich odrzucać w przypadkach procesów o czary"4. Wedle niego niemiecki historyk Hans Prutz zmarnował czas, pisząc krótkie studium o obaleniu templariuszy, w którym uznał, że zakon uległ degeneracji za sprawą zafascynowania mieszanką satanizmu i kataryzmu ${ }^{5}$.

O wiele mocniejsze zarzuty postawiono w toku procesu, który trwał przez pięć lat: od 1307 do 1312 r. Istota oskarżeń, co do których H.Ch. Lea i H. Prutz tak głęboko się nie zgadzali, tkwiła we francuskich nakazach aresztowania, datowanych na 14 września 1307 r. Nowicjusze, chcacy wstapić w szeregi zakonu, mieli trzykrotnie wyrzekać się Chrystusa. Osoba odbierająca przysięgę całowała nagich nowicjuszy również trzykrotnie: u podstawy kręgosłupa, w pępek i w usta. Wreszcie inicjowani musieli złożyć przysięge podporządkowania się temu, co zostało określone jako "okropny i wstrętny concubitus". Nowo przyjęty członek szybko się przekonywał, jak dalece w zakonie powszechne jest bałwochwalstwo $^{6}$. Historycy współcześni, niemalże bez wyjątku, przyjęli postawę H.Ch. Lei wobec powyższych oskarżeń. Niektórzy jednak czynili to $z$ pewna niechęcia, choć nie uformowała ich wiktoriańska interpretacja, co N. Cantor uznawał za bezcenna zaletę. Dla przykładu Jean Favier w swojej książce Philippe le Bel, wydanej w 1978 r., wyraził przekonanie, że zakon jako instytucja nie mógł być zdegenerowany, a jego jedyną winą było to, że miał pośród siebie osobników słabych i bezwiednych. J. Favier podtrzymał zatem, zaczerpnięte $z$ dokumentów procesowych, rozróżnienie na zakon $i$ indywidua go tworzace. Twierdził, że templariusze byli „twardymi ludźmi, którzy żyjąc na Wschodzie, zbyt blisko innych cywilizacji, nie ustrzegli się skażenia wynikającego $z$ kulturowej osmozy, co zanim przyniesie korzyści, rodzi problemy. Nie mieli należytego przygotowania, by dostrzec różnicę między prawda i kłamstwem oraz czynem nieszkodliwym i zbrodnia”. W konsekwencji ceremonię powitalna, określaną przez N. Cantora „rytuałem inicjacyjnym”, przepełniały religijna profanacja i „bizuthage”. „Brak kobiet i wpływ kultur Wschodu przyczyniły się do tego, że w głąb zakon-

${ }^{4}$ H.Ch. Le a, op. cit., s. 267.

5 H. Prutz, Geheimlehre und Gehesimstatuten des Templerherren-Ordens, Berlin 1879, s. 62, 86, 100.

6 Le Dossier de l'Affaire des Templiers, éd. et trad. G. Lizerand, Paris 1923, s. 18-21. Lewis i Short zinterpretowali słowo „concubitus” jako „kopulację”. 
nych praktyk przeniknęła sodomia. Wrogiem Światyni nie była Sodomia (pisana przez duże „S”), lecz zamknięte drzwi”.

Dwa lata później amerykański historyk Joseph Strayer opublikował prace zatytułowana The Reign of Philip the Fair, będaca owocem wieloletnich badań nad rzadami monarchy. J. Strayer, podobnie jak ja, zmitrężył trochę czasu na lekturę H.Ch. Lei, gdyż jego konkluzje dotyczące bezpodstawnych oskarżeń wywodzą się $z$ ustaleń amerykańskiego badacza, że „templariusze, których spalono na stosie, zostali nań skazani, ponieważ trwali przy swoich oświadczeniach, aczkolwiek nie wynikało to $z$ chęci bronienia własnych przekonań”. J. Strayer konfrontuje powyższa postawę z zachowaniem katarów w XIII w., pragnących udowodnić swe oddanie wyznawanym poglądom $\mathrm{w}$ płomieniach stosów rozniecanych przez krzyżowców. Podobnego zdania był J. Favier, chociaż jego osąd, jakkolwiek niechętny, jest $\mathrm{w}$ istocie taki sam. Uważał, że w zakonie złożonym $z$ samych mężczyzn homoseksualizm stanowił zjawisko nieuniknione. Uznał, że „rzeczy obsceniczne i bluźniercze, jakie działy się $\mathrm{w}$ siedzibach templariuszy, wynikały $z$ sytuacji generowanej przez takie grupy, szczególnie gdy inicjowano nowych członków zakonu". W przeciwieństwie do J. Faviera J. Strayer przyznaje, że templariusze byli "wystarczajacco inteligentni”, by stworzyć spójny zestaw heretyckich doktryn, jednakże autor nie dostrzega powodów, dla których mieliby to uczynić ${ }^{8}$. Aż nadto widać konflikt między analiza historyczna a osobistymi uprzedzeniami, które trapiły J. Strayera. Nie bez znaczenia mogła być sugestywna postawa jego przyjaciela, Roberta Fawtiera, przekonanego o bezsensowności roztrząsania powodu potępienia i skazania templariuszy, skoro najbardziej prawdopodobnym rozwiąaniem było to, że sami uwierzyli w swoją winę 9 . J. Strayer przyznał niegdyś na marginesie swojej pracy, że R. Fawtier powiedział mu, iż templariusze byli "grzesznymi ludźmi”. Jednakże to historyk wcześniejszej generacji, Guillaume Mollat, okazał się najbardziej stanowczy w swoich twierdzeniach, uznając, że „brak materialnych dowodów, nieprawdopodobieństwo zarzutów, sprzeczna natura oświadczeń, brutalne metody stosowane podczas przesłuchań, odwaga broniących zakonu -

7 J. F avie r, Philippe le Bel, Paris 1978, s. 473, 444, 447. Bizuthage - rytualna inicjacja powiązana $z$ przemoca fizyczna i psychicznym poniżeniem.

8 J.R. Str a y e r, The Reign of Philip the Fair, Princeton 1980, s. 291-292.

9 R. F aw ti e r, L'Europe occidentale de 1270 à 1380, [w:] Histoire du Moyen Age, t. VI, Paris 1940, s. 416, 423-424. 
wszystko to dowodzi niewinności templariuszy. Cały proces był oszustwem, noszacym bez wattpienia znak Wilhelma de Nogaret" 10 .

Mimo okazjonalnych wybuchów homofobii wydaje się, że między współczesnymi historykami zapanował consensus co do braku winy templariuszy odnośnie do zarzucanych im czynów. Brak jednak powszechnej zgody, gdy przychodzi do pytań wynikających $z$ tych poglądów. Jeśli templariusze nie byli bluźniercami, bałwochwalcami i sodomitami, dlaczego ich aresztowano i wytoczono im proces? Jak można było zlikwidować zakon kościelny, którego członkowie od prawie dwóch wieków stanowili trzon chrześcijańskich armii w państwach krzyżowców?

Oczywiste jest, że historycy tacy jak R. Favier i R. Strayer, odrzucając zarzuty sprokurowane przez dwór francuski, nie uważają jednocześnie, by w zakonie wszystko było na swoim miejscu. Jednak żaden $z$ nich nie zastanawia się, dlaczego akurat to pokolenie templariuszy miało być bardziej podatne na „wpływy Wschodu” w kwestiach niechrześcijańskiej ideologii, homoseksualizmu i innych zachowań seksualnych aniżeli templariusze $z$ wcześniejszego okresu. $Z$ drugiej strony, jeśli mają na myśli, że takie przekonania i praktyki nie były rozpowszechnione, nie próbują wyjaśnić, dlaczego upłynęło niemalże 200 lat, nim władze podjęły stosowne działania, by temu przeciwdziałać. W istocie przed lub w czasie procesu odnalezienie dowodów na nieobyczajność jest wyjątkowo trudne. Historycy kategoryzuja, że zakony wojujące wykazywały niewielka potrzebę częstych, wewnętrznych zmian, co ich zdaniem jest konieczne do poprawnego, zdrowego i długiego funkcjonowania każdej instytucji. Prawda jest, że trzynastowieczni templariusze nie mieli w swoich szeregach nikogo na miarę Stefana Lexingtona, członka zakonu cystersów, który świadom upadku swego zgromadzenia, chciał podjać dzieło jego naprawy. Inna kwestia jest to, że dostojnicy stojący na czele templariuszy w 1307 r. byli już mężczyznami w zaawansowanym wieku. Wielki mistrz Jakub de Molay służył już od 42 lat, wizytator Hugon de Pairaud od 40, preceptor Normandii Godfryd de Charney od 37 lub 38 lat ${ }^{11}$. Taki stan rzeczy mógł się zapewne przyczynić do powstania konserwatywnego etosu, szczególnie wtedy, gdy, jak możemy się przekonać $z$ dokumentów procesowych, większość członków zakonu pochodzących $z$ terenów Francji była w średnim wieku. Zdanie wygłoszone przez J. de Mo-

10 G. M o1l a t, The Popes at Avignon, transl. J. Love, London 1963, s. 245.

11 Le Dossier..., s. 30-31, 34-35, 38-39. 
laya, że „ryzyko zmian nigdy lub z rzadka obywa się bez wielkich niebezpieczeństw", może służyć za potwierdzenie powyższych słów ${ }^{12}$.

Racja, że reguła zakonu nie była statycznym dokumentem, niepoddawanym zmianom. Uzupełnienia $w$ języku francuskim wprowadzono między 1165 i 1187 r. oraz ponownie między 1257 i 1267 r. Klauzule te zawierały opisy rozbudowanego systemu kar, stopniowanych stosownie do wagi przewinienia. Pod zwierzchnictwem Tomasza Berarda w latach 1256-1273 dodano także szczegółowe przypadki historii, mogących pomóc w interpretacji wykroczeń, gdyby władze zakonu miały nałożyć na kogoś karę. Dotyczyły one symonii, bezpieczeństwa wewnętrznego, zabójstw, kradzieży, spiskowania, ucieczki do Saracenów, odejścia od wiary chrześcijańskiej, homoseksualizmu, dezercji z pola bitwy oraz udzielania święceń bez zezwolenia ${ }^{13}$ i wielu innych pomniejszych wykroczeń, których spis osiagnął prawie 112 klauzul. Ta troska, w połaczeniu $z$ systematycznymi akcjami legislacyjnymi dotyczacymi kar, była powiąana $z$ ówczesnymi praktykami $\mathrm{w}$ Kościele oraz $\mathrm{z}$ prawem kanonicznym i konstrukcja szczegółowych penitencjałów. Wydaje się, że zarówno szpitalnicy pod wodzą Hugona Revela (1258-1277), jak i templariusze za rządów T. Berarda doświadczyli zmian wewnętrznych w swych zgromadzeniach, w zbliżonym do siebie czasie. Prawdopodobnie była to odpowiedź na wzajemne animozje i wrogość, w szczególności po wojnie domowej „świętego Saby” toczonej w latach 1256-1258, kiedy zakony stanęły po przeciwnych stronach, a wszystko to w czasie, gdy zagrożenie ze strony Mongołów i Mameluków stawało się coraz poważniejsze ${ }^{14}$.

Potrzeby nadzoru i naprawy błędów wewnętrznych w zakonie były spójne $z$ wypełnianiem przezeń roli obrońcy pielgrzymów i zabezpieczenia Ziemi Świętej. Anonimowy autor opisujący odbudowę przez templariuszy zamku Safed w Galilei w latach 12611266 za główna zaletę zakończenia prac uznał to, że „teraz można

12 Ibidem, s. 4-5.

13 Le Regle du Temple, éd. H. de Curzon, Paris 1896, §§ 544-86, s. 285-305.

14 Por. J. Rile y-S mith, The Knight of St. John in Jerusalem and Cyprus c. 1050-1310, London 1967, s. 187. Tekst łaciński statutów Hugona Revela do odnalezienia w Customs of Hospitallers, t. III, nr 3075 (s. 75-77), 3104 (s. 91), 3180 (s. 118-121), 3317 (s. 186-188), 3396 (225-229). Tłumaczenie anglojęzyczne E.J. King, The Rule, Statutes, and Customs of the Hospitallers 1099-1310, London 1934 , s. 53-78. Kolejnych pięciu następców H. Revela kierowało się stworzonymi przez niego statutami. 
nawiedzać słynne miejsca leżące w pobliżu zamku Safed"15, zatem odzyskano dla pielgrzymów dostęp do galilejskich miejsc kultu. Katastrofa roku 1291 [czyli upadek Akki] nie zmieniła podstawowych celów zakonu. J. de Molay od początku objęcia funkcji wielkiego mistrza realizował aktywnie plan krucjatowy, w którym poczesne miejsce zajmowała perspektywa wojennych zmagań we wschodnim regionie Morza Śródziemnego. Pośród wysiłków podjętych przez templariuszy było wyekwipowanie sześciu galer w Wenecji w 1293 r., a następnie skierowanie ich na akweny cypryjskie. Ponadto wzięcie udziału w ataku morskim na egipskie i palestyńskie wybrzeża w $1300 \mathrm{r}$. oraz próbę umieszczenia w latach 13001302 garnizonu na wyspie Ruad koło Tortosy uznano za wstęp do odzyskania bazy templariuszy $\mathrm{w}$ mieście. W tym samym czasie statki płynace $z$ Francji, Anglii i Sycylii wiozły nowych rekrutów, a także zapasy pieniędzy i materiałów niezbędnych do prowadzenia walki. Na Boże Narodzenie 1294 r. J. de Molay osobiście odwiedził papieża Bonifacego VIII, a w roku następnym podjął kosztowna wyprawę do Francji i Anglii, gdzie wziął udział w posiedzeniu kapituł. Dbano o kontakty $z$ Karolem II Neapolitańskim i Jakubem II Aragońskim ${ }^{16}$, co nie było łatwe, gdyż monarchowie wspomnianych czterech królestw nieufnie traktowali swe wzajemne relacje, mimo wspólnego celu, jakim było zorganizowanie krucjaty. Niemniej przywódców templariuszy można było aresztować jedynie w Pary$\dot{z ̇ u}$, gdzie przebywali w 1307 r. w celu omówienia dalszych planów krucjatowych $z$ papieżem Klemensem V. Projekt taki musiał mieć odpowiednie oparcie w stosownie licznej armii. Najnowsze badania dotyczace struktury wiekowej zakonu templariuszy w późnym wieku XIII i u progu wieku XIV, oparte na dokumentach procesowych, pokazują, że zakon kontynuował praktykę wysyłania młodych mężczyzn do walki za morze, podczas gdy stanowiska na Zachodzie obsadzano braćmi starszych wiekiem. Anna Gilmour-Bryson wykazała, że przystępujący do zgromadzenia rycerze zasadniczo byli w młodszym wieku aniżeli bracia służebni czy księża już będący w zakonie. Odzwierciedlało to różnicę funkcji pełnionych w zgromadzeniu. Prawie 65\% rycerstwa wstępowało do zakonu w wieku poniżej 21 lat. Na podstawie dostępnych źródeł A. Gilmour-Bryson

15 De constructione castri Saphet, éd. R.B.C. Huygens, „Studi Medievali” 1965, série 3, vol. VI, s. 386.

16 Por. M. B a r b e r, James of Molay, the Last Grand Master of the Temple, „Studi Medievali” 1972, vol. XIV, s. 94-100. 
oszacowała, że na Cyprze, znajdującym się od 1291 r. na „linii frontu", przebywało co najwyżej 37 rycerzy, a tylko jeden był mężczyzną ponad pięćdziesięcioletnim (miał najprawdopodobniej 52 lata). Pośród templariuszy obecnych na wyspie w 1310 r. jedynie dwóch pojawiło się tam przed upadkiem Akki. Jeśli policzyć zarówno rycerzy, jak i obsługę, to okaże się, że ledwie $7 \%$ templariuszy na Cyprze miało 50 lub więcej lat, co wyraźnie kontrastuje z Paryżem, gdzie liczba ta wynosiła 40\% (rozbieżność tę potwierdził także w swoich badaniach Alan Forey) ${ }^{17}$. Pośród braci przesłuchiwanych na Zachodzie w latach 1309-1311 najwyższy procent mężczyzn poniżej 10 lat służby został odnotowany na Wyspach Brytyjskich - 36\%. Jednak na Cyprze liczba ta sięgnęła 64\%. Pośród przesłuchiwanych w 1310 r. templariuszy 46 z 72 wstapiło do zakonu po 1300 r. $18 \mathrm{~W}$ swietle tych danych oraz na podstawie prac Elizabeth Siberry, Normana Housleya i Sylvii Schein, którzy szerzej przyjrzeli się ideom krucjatowym schyłku XIII i początku XIV w. ${ }^{19}$, byłbym teraz znacznie ostrożniejszy niż 20 lat temu, prezentując zakon templariuszy, którego początek i koniec związany był $z$ idea ruchu krucjatowego, i który osiągną swój szczyt w XII i poczatkach XIII w. ${ }^{20}$ Dokumentacja nie sugerowała, by Filip Piękny zaatakował w 1307 r. apatyczny, dekadencki, ginacy zakon. Wątpliwe wydaje się również, aby jakikolwiek historyk zasugerował inna przyczynę tak dramatycznego końca templariuszy niż sam proces.

Skoro w zakonie trudno znaleźć powody, $z$ racji których wszczęto proces, bardziej owocne wydaje się przestudiowanie roli i motywacji oskarżycieli. Zarówno dla mnie, jak i dla H.Ch. Lei chęć położenia ręki na bogactwach Zakonu wydawała się oczywista. Ale i ten badacz stwierdził, że „w celu wyjaśnienia działań Filipa musimy rozważyć nie tylko pobudki finansowe"21. Daleko mu jednak do postrzegania Filipa IV jako „wielkiego króla”, tak jak to uczynił

17 A. Gilm o u r-B ry s o n, Age-Related Data from the Templar Trials, [w:] Aging and the Aged in Medieval Europe, ed. M.M. Sheehan, Toronto 1990, s. 130-142.

18 A.J. F o r e y, Towards a Profile of the Templars in the Early Fourteenth Century, [w:] Military Orders, t. I, s. 196-204.

19 Por. E. Siberry, Criticism of Crusading 1095-1274, Oxford 1985; S. Schein, Fideles Crucis. The Papacy, the West, and the Recovery of the Holy Land 1274-1314, Oxford 1991; N. H o u s le y, The Later Crusades. From Lyons to Alcazar 1274-1580, Oxford 1992.

20 Por. M. B a r b e r, The Trial of the Templars, Cambridge 1978, s. 5.

${ }^{21}$ H.Ch. Le a, op. cit., s. 254. 
R. Fawtier ${ }^{22}$. Wydaje mi się, że Filip miał do czynienia $z$ seria nigdy niekończących się kryzysów, na rozwiązanie których nie miał absolutnie żadnego pomysłu. Początek rząów był zły, gdyż kraj obciążały długi po katastrofalnej krucjacie aragońskiej, zorganizowanej przez ojca Filipa. Wyprawa kosztowała przynajmniej 1220000 liwrów tureńskich (przydatna miara porównawcza jest wystawna wyprawa Ludwika Świętego $z$ lat 1248-1254, która kosztowała 1500000 liwrów) ${ }^{23}$. Jednak od 1294 r. król wciagnał kraj w nowa serię konfliktów z Edwardem I. Malcolm Vale sugeruje, że Filip poczuł się upokorzony, gdy Edward I - „faktyczny wasal korony francuskiej" - odegrał główną rolę w zakończeniu aragońsko-francuskiego konfliktu $z$ lat 1287-1288. Najwyraźniej Edward nie postrzegał siebie jako kogoś gorszego niż Kapetyngowie ${ }^{24}$. Skoro tak, Filip gotów był się wyekspensować w celu przywrócenia dumy swojej dynastii. Minimalny koszt wojny $\mathrm{z}$ Anglia między 1294 a 1299 r. wyniósł 1730000 liwrów, co doprowadziło królestwo do „ogromnego zadłużenia"25. Niewydolność finansowa Kapetyngów wcią̇ się pogłębiała, tym bardziej że Korona nie mogła odnieść zwycięstwa w tym konflikcie, jak i w konflikcie $z$ Flandria, co przyniosło dodatkową hańbę $\mathrm{w}$ postaci porażki w bitwie pod Courtrai w 1302 r. Szczegółowa analiza J. Strayera dotycząca finansów, ogłoszona jeszcze w 1939 r. ${ }^{26}$, pokazuje, jak wymyślnie poszukiwano nowych środków dochodu $\mathrm{i}$ jak łączyło się to $z$ fiaskiem ustanowienia nowego porzadku podatkowego. Konfrontacja $z$ Bonifacym VIII, która przypadła na lata 1296-1297 i dotyczyła opodatkowania duchowieństwa, jak również psucie monety w okresie 1294-1306, były kwestiami wskazujacymi na „krótkowzroczność” władzy. Używając słów M. Vale’a: „by z powodzeniem prowadzić wojny, o czym przekonali się Francuzi w Aragonie i Flandrii, Angli-

22 R. F aw ti e r, The Capetian Kings of France, transl. L. Butler, R.J. Adam, London 1965, s. 35.

23 J.R. S t r a y e r, The Crusade against Aragon, „Speculum” 1953, vol. XXVIII, s. 102-113; W.C. J or d a n, Louis IX and the Challenge of the Crusade, Princeton 1979 , s. $78-79$.

24 M. V a le, The Angevin Legacy and the Hundred Years War 1250-1340, Oxford 1990, s. 177-178.

25 J.R. Straye r, The Costs and Profits of War: The Anglo-French Conflict of 1294-1303, [w:] The Medieval City, eds H.A. Miskimin, D. Herlihy, A.L. Udovitch, London 1977, s. 272-273; M. V a le, op. cit., s. 207-208, 225-226.

26 J.R. Straye r, C.H. Taylo r, Studies in Early French Taxation, [w:] Harvard Historical Monographs, t. XII, Cambridge 1939, s. 3-105. 
cy w Szkocji, a następnie obie te siły w Akwitanii, niezbędne były nakłady środków finansowych, zwiększenie sił ludzkich i zapasów, które leżały daleko poza możliwościami stron" 27 . Nie jest więc niespodzianka, czego dowiodła Sophia Menache, że wielu ówczesnych i późniejszych obserwatorów spoza Francji, szczególnie szlachty i duchowieństwa, nie przekonywała argumentacja dworu forsujacca konieczność działań przeciwko narastającemu niebezpieczeństwu ze strony heretyków konspirujacych wewnattrz zakonu templariuszy 28 .

Warto o tym pamiętać, gdyż w przeciwieństwie do H.Ch. Lei współcześni historycy uznali za konieczne przyjrzeć się czynnikom wykraczającym poza finansowe rozważania, skupiając uwagę szczególnie na osobowości Filipa Pięknego i jego relacjach $z$ prominentnymi doradcami. R. Fawtier, odwrotnie niż H.Ch. Lea, uważa, że „opieszałość, z jaką zajmowano się tą afera, niewielki opór króla w kwestii dóbr templariuszy, fakt, że mógł pozyskać od zakonu pieniądze, których potrzebowal, uprawniają do odsunięcia na bok motywu chciwości". Nie przekonuje go również strach przed templariuszami $z$ uwagi na łatwość, $z$ jaka dokonano aresztowań. Jego zdaniem odpowiedzi trzeba szukać w splocie zdarzeń wynikajacych $z$ pobożności Filipa. O ile król „nieustannie pragnał krucjaty, którą, jak wierzył, można było zorganizować dzięki zjednoczeniu zakonów", o tyle J. de Molay równie silnie przeciwstawiał się tej idei - i to $\mathrm{w}$ czasie zbiegającym się $z$ oskarżeniami wysuniętymi pod adresem zakonu. Filip uznał to za prawdziwa opinię, wzmocniona pierwszymi zeznaniami. R. Fawtier uważa, że zeznania „najprawdopodobniej wspomagano torturami. [...] Dzisiaj deprecjonowałoby to wartość takich oświadczeń, jednakże dla ludzi $z$ początków XIV w. była to normalna procedura stosowana w procesach kryminalnych". Filip był wstrzasśnięty tym, czego się dowiedział, i obawiał się, że Kościół pobłażałby sobie w tej sprawie, ścigał

27 M. V a le, op. cit., s. 176.

28 S. M e n a che, Contemporary Attitudes Concerning the Templars' Affair: Propaganda's Fiasco?, "The Journal of Medieval History” 1982, vol. VIII, s. 135147; e a d e m, The Templar Order: a Failed Ideal?, „The Catholic Historical Review" 1993, vol. LXXIX, s. 1-21. W artykule tym autorka przekonuje, że atak wymierzony w templariuszy był jedynie częścią działań politycznych zakrojonych na szersza skalę. Miały one na celu usunięcie "obcych" (włączając w to Lombardów i Żydów) $z$ pełnienia ważnych funkcji w administracji państwowej, co $z$ kolei otwierało drogę rosnacemu w siłę mieszczaństwu. [Lombardowie - bankierzy i przedsiębiorcy z północnych Włoch - przyp. tłumacza]. 
więc templariuszy $z$ chrześcijańskim zapałem. Dla monarchy sprawa ta stała się „aktem wiary”29.

Robert Fawtier oparł się tylko na małym fragmencie rękopisu dotyczącego lat 1270-1328. Dokładniejsza analizę przedstawiła Elizabeth Brown w długim i genialnym artykule. Autorka argumentuje, że mimo trudności dokumentacyjnych możliwa jest rekonstrukcja głównych cech osobowości króla i wskazanie na ich zwiąek $z$ wieloma "dramatycznymi i ważnymi wydarzeniami” jego panowania ${ }^{30}$. Dostrzega, że klucz leży w moralizatorskiej i cenzorskiej naturze monarchy, w znacznym stopniu ukształtowanej $\mathrm{w}$ okresie dzieciństwa, kiedy to nieustannie przypominano mu o świętych przymiotach jego dziadka [Ludwika IX], którego reputacja rosła ze spadkiem reputacji jego ojca. Jednocześnie Filip żył $\mathrm{w}$ świecie niewytłumaczalnych śmierci, buntów i potencjalnych zagrożeń dla jego bezpieczeństwa. Szybko stracił matkę i dwóch braci, a jego macochę, Marię $z$ Brabancji, oskarżono o otrucie chłopców, spośród którego jeden był przewidziany na następcę tronu. Mówiono, że planowała przejęcie władzy dla syna, Ludwika $z$ Evreux, który miał większe prawa do tronu jako bliższy potomek Karola Wielkiego. Już od młodych lat Filip okazywał pobożność przez odprawianie pokuty i zachowywanie wstrzemięźliwości, czego dowodem było także noszenie włosiennicy. W kontekście tych doświadczeń $z$ dzieciństwa pewien stopień zaburzeń urojeniowych nie stanowi niespodzianki. Zdaniem E. Brown źródła ukazuja Filipa jako mężczyznę „małostkowego, o surowej moralności, niezwykle dokładnego, pozbawionego humoru, upartego, agresywnego i mściwego, który obawiał się pośmiertnych konsekwencji swych doczesnych postępków"31. Sposób rządzenia odzwierciedlał tę osobowość. Rządy Filipa były naznaczone „bezprecedensowym szukaniem podobieństw między jego decyzjami a wyrokami Bożymi”. Jak stwierdziła E. Brown, „wiele posunięć Filipa, jak na przykład kam-

29 R. F a w ti e r, L’Europe..., s. 423-424. O wyrażenie opinii poproszono również Fulka de Villaret, wielkiego mistrza szpitalników, ale jego zapis nie przetrwał do naszych czasów. Schein uważa, że w innych źródłach można odnaleźć wskazówki, że Fulko skłaniał się ku pomysłowi zjednoczenia zakonów. Jednak J. Strayer uznał, że w konsekwencji porażki w Aragonii Filip stracił zapał do zorganizowania krucjaty, a wspomnienie klęski rzutowało na jego nastawienie do papiestwa i sprawowanie rządów.

30 E.A.R. B r ow n, The Prince is Father of the King: the Character and Childhood of Philip the Fair of France, „Medieval Studies” 1987, vol. XLIX, s. 282-334.

31 Ibidem, s. 315. 
pania przeciwko Bonifacemu VIII i wysiłki, by upokorzyć Flamandów, skazanie kochanków królewskich synowych, sugeruja, że osoba odpowiedzialna za te czyny identyfikowała się $z$ siłą wyższa i nie miała watpliwości w wymierzaniu kary doczesnej za moralne uchybienia" 32 .

Nie można ignorować ówczesnych nastrojów, gdyż proces templariuszy nie był odizolowanym przypadkiem. W odróżnieniu od innych procesów we Francji są sygnały rosnącego poczucia chrześcijańskiej wyjątkowości, przejawianej w zaostrzaniu postaw wobec mniejszości religijnych w całej Europie, począwszy od usunięcia Żydów z Anglii w 1290 r., przez wydalenie muzułmanów z apulijskiej Lucery w 1300 r., aż po traktowanie trędowatych, homoseksualistów i czarownic jako sił zagrażajacych wspólnocie chrześcijańskiej. W tym kontekście nagłe zniszczenie społeczności muzułmańskiej $\mathrm{w}$ Lucerze jest istotne, gdyż sprowokowało takie same pytania o pobudki kierujacce Karolem II, jak w przypadku Filipa Pięknego i templariuszy. Karol wydawał w tym czasie duże sumy pieniędzy, by odzyskać Sycylię Fryderyka Aragońskiego. Podobnie jak we Francji, tak i tutaj wojna doprowadziła do finansowego kryzysu. David Abulafia szukał wyjaśnienia, które nie jest tak „dosadnie materialistyczne” i zasugerował, że Karol, bratanek Ludwika IX, święcie wierzył $\mathrm{w}$ to, że jego obowiązkiem było oczyszczenie ziemi z trucizny, jaka stanowili Saraceni - „nienawistni i wrodzy chrześcijaństwu". D. Abulafia nie negował równorzędności spraw materialnych i religijnych. „Pobudki religijne nie wykluczają faktu, że Karola zachwycała perspektywa szybkich korzyści ze sprzedaży ludności oraz pozyskania jej upraw i dobytku dla pomnożenia wojennych kosztów"33.

Jawne zarzuty wobec templariuszy o zinstytucjonalizowany homoseksualizm trudno uznać za zbieg okoliczności, gdy w tym samym czasie oskarżenia o czary znajdowały się na końcu penitencjarnej listy. Homoseksualizm to temat, któremu współcześni historycy bacznie się przyglądają. Jakkolwiek Michael Goodich, John Boswell i James Brundage różnią się w rozłożeniu akcentów, to jednak $\mathrm{w}$ ich pracach opublikowanych w późnych latach sie-

32 Ibidem, s. 288-289.

33 D. A bulafia, Monarchs and Minorities in the Christian Western Mediterranean around 1300: Lucera and its Analogues, [w:] Christendom and its Discontents. Exclusion, Persecution and Rebellion, 1000-1500, eds S.L. Waugh, P.D. Diehl, Cambridge 1996, s. 234-263. 
demdziesiątych widać wspólny punkt widzenia, wedle którego wzrost wrogości wobec homoseksualistów przybrał na sile przynajmniej w połowie XIII w. Ostre przepisy określały to jako przestępstwo „wbrew naturze” i traktowały na równi $z$ herezją ${ }^{34}$. Potępienie tych zachowań przez św. Pawła i św. Augustyna znalazło wyraz prawny za czasów Justyniana w latach 538/539 i 559, gdy homoseksualizm uznano za diabelski, co znamienne w perspektywie oskarżenia wysuwanego przeciw templariuszom. Tolerancja mogła przynieść jedynie katastrofę. Kanoniści potraktowali to $z$ taka powaga, że do końca XII w. nawet utrzymywanie kazirodczych stosunków między matka i synem było rozpatrywane jako lżejsze przewinienie. Nic więc dziwnego, że wedle ówczesnych pisarzy zarówno wewnętrzni, jak i zewnętrzni wrogowie, czyli katarzy i muzułmanie, mieli skłonności do praktykowania homoseksualizmu, podczas gdy - jak wykazał Robert Lerner - literacki topos powiazania herezji $z$ seksualnymi ekscesami pojawił się w XIII w. ${ }^{35}$ Francuskie władze wykorzystywały te oskarżenia nie tylko przeciwko templariuszom, lecz także przeciw Bonifacemu VIII i Guichardowi de Troyes. To jakaś ironia, że templariusze, podzielając zapewne wspomniane poglądy, byli bardziej niechętni w przyznawaniu się do sodomii aniżeli do innych przewinień, włączajacc $\mathrm{w}$ to zapieranie się Chrystusa ${ }^{36}$. Jak wykazała E. Brown, Filip Piękny był szczególnie wyczulony na tego typu postawy. Oburzenie dotyczące kochanków jego synowych z 1314 r. dowodzi „wrażliwości na

34 M. G o o d ic h, The Unmnetionable Vice: Homosexuality in the Later Medieval Period, Oxford 1979, s. XV, 51-88; J. B o s w e 11, Christianity, Social Tolerance and Homosexuality. Gay People in Western Europe from the Beginning of the Christian Era to the Fourteenth Century, London 1980, s. 37-38, 269-291; J. B r u n d a ge, Law, Sex, and Christian Society in Medieval Europe, London 1987, s. 313, 398-399, 472-473. Miernikiem wskazujacym na zmiany zachodzace w ludzkich postawach, dotyczace powyższych zagadnień, może być moja pierwsza próba zagłębienia się w problematykę homoseksualizmu. We wczesnych latach siedemdziesiątych XX w. obsługa British Museum najwyraźniej uznała, że lekturę książki D. Sherwin-Bailey, Homosexuality and the Western Christian Tradition, London 1955, powinienem odbywać w specjalnie wybranym miejscu w Bibliotece Północnej, siedząc naprzeciwko dyrektora placówki. Takie zachowanie może w pewien sposób tłumaczyć punkt widzenia J. Strayera i R. Fawtiera.

35 J. Bru nd a ge, op. cit., s. 121-122, 399; R.E. Le rne r, The Heresy of the Free Spirit in the Later Middle Ages, London 1972, s. 20-25.

36 Procès..., s. 290, 294. Przesłuchania przeprowadzone w październiku i listopadzie 1307 r. w Paryżu opisuje trzech spośród łącznej liczby 138 templariuszy, którzy przyznali się do praktykowania homoseksualizmu. 
oskarżenia pod adresem czystości seksualnej”. Tym bardziej że w 1276 r. jego ojca, Filipa III, oskarżono o „grzeszenie przeciwko naturze", czemu towarzyszyło ostrzeżenie, że jeśli król nie zmieni swojego zachowania, jeden $z$ jego synów umrze $w$ ciagu sześciu miesięcy. Istotnie, tego samego roku zmarł następca tronu, Ludwik ${ }^{37}$. Dla Filipa Pięknego przypowieść o zniszczeniu Sodomy i wnioski $z$ tego płynące były czymś więcej niż tylko literackim zabiegiem drugorzędnych kronikarzy.

Już we wczesnych latach XIV w. stereotyp sodomity jako siły antyspołecznej, często powiązanego $z$ herezją czy nawet islamem, był już silnie zakorzeniony. Uprawianie czarów było trudniejsze do udowodnienia, ale bynajmniej nie podważane. Poza ewidentnym oskarżeniem templariuszy o homoseksualizm pozostałe zarzuty koncentrują się na sekretnych ceremoniach, trzonem których było zapieranie się Chrystusa i adorowanie bożka, najprawdopodobniej reprezentujacego demoniczne moce, co XIII-wieczni pisarze zdawali się przyjmować bez zastrzeżeń. Norman Cohn w wydanej w 1975 r. książce Wewnętrzne demony Europy, w rozdziale poświęconym templariuszom, uznał ich katastrofę za istotny etap średniowiecznej walki $z$ czarna magia głównie dlatego, że zaparcie się Chrystusa znalazło się po raz pierwszy w centrum oskarżenia ${ }^{38}$. Podobnie Richard Kieckhefer w swojej pracy Europejskie procesy czarownic, dotyczacej lat 1300-1500, opublikowanej w 1976 r, umieszcza proces templariuszy $\mathrm{w}$ okresie rosnącej wiary $\mathrm{w}$ czarnoksięstwo, a przynajmniej wówczas, kiedy tego typu oskarżenia nabierały istotnego znaczenia w walce $z$ przeciwnikiem. R. Kieckhefer znalazł niewiele źródeł pochodzących sprzed 1300 r., w przeciwieństwie do świadectw z lat między 1300 a 1330 r., wedle których w całej Europie przeciętnie raz $\mathrm{w}$ roku odbywał się proces o czary, a ponad połowę tej liczby stanowiły procesy we Francji. Te dane zawieraja w sobie słynne sprawy Bonifacego, templariuszy i Guicharda de Troyes za rząów Filipa IV oraz byłego szambelana Enguerrana de Marigny za rząów Ludwika X, ponadto kolejne siedem przypadków $z$ lat 1316-1331, które R. Kiechkhefer wiąże ze wzrastającymi obawami dynastii, mierzacej się $z$ problemem wygaśnięcia, mimo

37 E. Brown, op. cit., s. 326, 332. Szersze ujęcie historiograficzne por. A. Gilmour-Brys on, Sodomy and the Knights Templar, „Journal of the History of Sexuality" 1996, vol. VII, s. 151-183.

38 N. C o h n, Europe's Inner Demons, London 1975, s. 75-98. 
dzierżenia władzy od X w. ${ }^{39}$ Badacz nie wspomniał o panice wywołanej rzekomym spiskiem trędowatych, Żydów i władców Granady, by pokonać chrześcijaństwo, co miało chwilowo osłabić rządy Filipa V w 1321 r. Wedle mnie wszystko to wiąże się $z$ obawami przed czarnoksięstwem i wskazuje na paranoiczne nastroje ${ }^{40}$. W tym samym czasie francuski papież Jacques Duèze, który w 1316 r. przybrał imię Jana XXII, był również ogarnięty tą obsesją, czyniąc na papieskim dworze atmosferę podobna do aury panującej na dworach ostatnich Kapetyngów. J. Duèze dobrze znał proces templariuszy, należąc do przedstawicieli duchowieństwa przygotowujących dla Klemensa V raporty z postępów procesu podczas soboru w Vienne w 1311 r. J. Duèze najwyraźniej uwierzył, że antychrześcijańskie doktryny przeniknęły zakon ${ }^{41}$. R. Kieckhefer zanotował, że procesy dotyczyły wysoko sytuowanych grup czy pojedynczych osobników o znacznej pozycji politycznej, którzy równie dobrze mogli być ofiarami lub sprawcami ${ }^{42}$. Studia R. Kieckhefera przynoszą celne wnioski dla naszych rozważań. Opierając swoje argumenty na dokumentacji pochodzącej z 35 procesów z XIV i XV w., badacz przyznaje, że podczas gdy wielu ludzi oddawało się magii, czego wyrazem było wyrządzane krzywdy przez oszpecanie twarzy czy stosowanie trucizn, to zachowania diaboliczne, czyli oddawanie czci złu i demonom w jakiejś zbiorowej formie, stanowiło tylko „produkt spekulacji teologów i jurystów”43, którzy narzucili swój punkt widzenia i wydobywali zeznania za sprawa inkwizycyjnych procedur. Magia nie mogła się poczać w wykształconych umysłach, toteż dopatrywano się ingerencji siły wyższej w postaci diabła czy demonów. Koncepcja demoralizujacej ceremonii towarzyszącej przyjęciu do grona templariuszy wydaje się zatem pomysłem jurystów króla Filipa IV aniżeli templariuszy, których, bez względu na ich indywidualne talenty, trudno zaliczyć w poczet ludzi wykształconych, co zaznacza R. Kieckhfeler.

Robert Ian Moore poszedł jeszcze dalej, uznając, że w końcu XII i na początku XIII w. wyraźnie pojawia się, jak to nazwał, „społe-

39 R. Ki e ck h e fe r, European Witch Trials. Their Foundations in Learned and Popular Culture 1300-1500, London 1976, s. 10-14, 108-112.

40 M. B a r b e r, Lepers, Jews and Moslems: the Plot to Overthrow Christendom in 1321, „History” 1981, vol. LXVI, s. 1-17; F. B e r i a c, La persécution des lépreux dans la France méridionale en 1321, „Le Moyen Age” 1989, vol. XCIII, s. 203-221.

${ }^{41}$ Por. V. V e r l a qu e, Jean XXII, sa vie et ses oeuvres, Paryż 1883, s. 52-53.

42 R. Ki e ck he fe r, op. cit., s. 10.

43 Ibidem, s. 36. 
czeństwo oprawców", ukształtowanych nie przez popularne przesądy czy prostacką agresję, ale uformowanych przez literati, którzy wykorzystując władzę otrzymaną dzięki służbie królowi, kreowali i ścigali określone grupy dla ugruntowania własnej dominującej pozycji. Wedle R.I. Moore'a powodowała nimi chęć wyeliminowania konkurencji rywalizujących ze soba Lombardów i Żydów, z jednoczesnym dyskredytowaniem wrogów wewnętrznych, przedstawianych jako „prostaków” czy „idiotów”, pozbawionych umiejętności posługiwania się piórem i zarządzania. Aby osiagnąc swój cel, wyolbrzymili zagrożenie kataryzmem i wykorzystali oskarżenia o „nienaturalne zachowania" przeciwko swoim politycznym oponentom. Dla R.I. Moore'a prześladowania sa nierozłączne $z$ dojściem tej grupy do władzy ${ }^{44}$. Jego książka nie wykracza poza rok 1250 , ale zapewne w podobny sposób widziałby okres następny, gdy opisane przezeń zachowania są bardziej wyraziste. Oskarżyciele templariuszy, przedstawiajacc ich jako wrogów chrześcijaństwa, potrafili manipulować wyobraźnią duchownych. Już w 1108 r., kiedy krzyżowcy oblegli Sydon, niemiecki kronikarz pierwszej krucjaty Albert $z$ Aachen powiązał naśmiewanie się $z$ krzyża, w szczególności opluwanie go i oddawanie na niego moczu, jako zachowania charakterystyczne dla apostatów i Saracenów, które potem zręcznie przypisano templariuszom ${ }^{45}$. Czy juryści Filipa Pięknego - zwłaszcza W. de Nogaret i Wilhelm de Plaisians - zachowuja się jak litera$t i$, używając oskarżeń o konspirację w celu wzmocnienia swojej pozycji, wiedząc, że król był aż nazbyt chętny, by postrzegać świat w ten sposób? Już król Jakub II Aragoński wyraził w tym względzie watpliwość. W grudniu 1307 r. powiedział Klemensowi V, że „podejrzewa, iż duża łatwowierność francuskiego władcy, podatnego na perswazję innych, może być łatwo wykorzystana"46. Robert-Henri Bautier, w opozycji do większości historyków, zgadza się $z$ tym poglądem. Widzi króla zdanego na doradców, zwłaszcza po 1305 r., czyli po śmierci żony, Joanny z Nawarry. R.-H. Bautier argumentuje, że plany królewskich podróży i jego dyplomatów wskazuja na rosnace zainteresowanie władcy odwiedzaniem klasztorów, uczestnictwem $\mathrm{w}$ pielgrzymkach $\mathrm{i}$ dotowaniem instytucji

44 R.I. M o o r e, The Formation of a Persecuting Society. Power and Deviance in Western Europe 950-1250, Oxford 1987, s. 124-153.

45 A lbe rt z Ache n, Historia Hierosolymitana, [w:] Receuil des Historiens des Croisades. Historens occidentaux, t. IV (1879), s. 653-654.

46 H. Prutz, Entwicklung und Untergang des Templeherrenordens, Berlin 1888 , s. 348. 
kościelnych. Kiedy 22 września 1307 r. W. de Nogaret stał się strażnikiem pieczęci, wykorzystał tę sytuację. Nie było trudno przekonać króla, że trzeba podjać pewne kroki w celu obrony wiary i królestwa. R.-H. Bautier cytuje notatkę $z$ tego dnia, sporządzona przez kancelaryjnego skrybę: „Panu rycerzowi Wilhelmowi de Nogaret powierzono pieczęć w czasie, gdy rozważano możliwość aresztowania templariuszy"47. E. Brown jest zdania, że Filip miał większa kontrolę nad tymi sprawami, niż sądzi R.-H. Bautier, jednak nawet ona przyznaje, że właśnie „ci mężczyźni mieli wpływ na króla. Przemawiali w jego imieniu, stawali między nim i jego podwładnymi; wręcz obnosili się ze swoją władzą"48.

Tezę R.I. Moore'a może podważyć w kilku przypadkach, bez uciekania się do najważniejszego argumentu, że dowody, którymi dysponujemy, pochodza od wykształconej elity, niezainteresowanej zdaniem ludu, nawet jeśli ono istniało. Jednocześnie Bernard Hamilton zwrócił uwagę, że prawo przeciwko trędowatym wyrosło głównie ze strachu przed zarażeniem, podczas gdy krzyżowcy nie tyle budzili zazdrość literati, ile prowokowali sytuacje sprzyjajace atakom na Żydów49. Istotnie, pozostając przy tezie R.I. Moore'a, powinniśmy równie jednakowo oczekiwać, by papież i jego otoczenie byli przekonani o winie templariuszy. Jednak ich zachowanie podczas procesu wyraźnie pokazuje, że nie byli. Dla przykładu: Wilhelm Rishanger, kronikarz z St. Albans, odnotował, że wedle Klemensa V templariusze cieszyli się dobra reputacją, co przyczyniło się do ich bogactwa i uprzywilejowania przez Kościół, toteż oskarżenia kierowane przeciwko nim go zdumiewały50.

47 R.H. B a u t i e r, Diplomatique et histoire politique: ce que la critique diplomatique nous apprend sur la personnalité de Philippe le Bel, "Revue Historique” 1987, vol. CCLIX, s. 3-27.

48 E. B r ow n, op. cit., s. 288.

49 B. Hamilton, recenzja w "The Heythrop Journal” 1990, vol. XXXI, s. 337339. Impuls do rozpoczęcia prześladowań często przychodził „z góry”, czasami był to ruch oddolny, a niekiedy rodził się $z$ kombinacji obu tendencji. Pogląd R.I. Moore'a wydaje się zbyt schematyczny, by odpowiadać każdemu przypadkowi rozpatrywanemu w interesujacym nas okresie. Por. R. C h a z a n, The Deteriorating Image of the Jews - Twelfth and Thirteenth Centuries, [w:] Christendom and its Discontents..., s. 220-233.

$50 \mathrm{~W}$ il h e $1 \mathrm{~m}$ R is h a ng e r, Chronica et Annales, éd. H.T. Riley, [w:] Rolls Series, t. XXVIII, s. 496-497. Sprawozdanie aragońskiego ambasadora, Jana Burgundzkiego, dotyczące przemówienia papieża $z$ czerwca 1308 r. w Poitiers, por. H. Finke, Papsttum und Untergang des Templeordens, Monachium 1907, s. $148-150$. 
Jednak dane o działalności templariuszy, jakimi dysponujemy po 1291 r., i nastawieniu ludności w tym okresie, a których brakowało wcześniej, nie wywołałyby zapewne aż takiej dysputy prowadzącej do odbytego procesu. Teraz stało się jasne, że nie było żadnego powszechnego przekonania o "heretyckiej deprawacji” templariuszy czy wiary w ich diaboliczność, dopóki nie ogłosili tego prawnicy Filipa Pięknego. Twierdzenie W. de Plaisians więc, że „jak się powiada, $z$ ich winy utracono Ziemię Świętą, i mówi się również, że zawierali oni często sekretne przymierza $z$ sułtanem" 51 , nie tylko wprowadziło w błąd całą generację historyków krucjat, ale pozostaje $\mathrm{w}$ istocie oderwane od tematu, gdyż zagadnienia, o których mowa, dotyczyły bardziej francuskiej polityki wewnętrznej niż wysiłku templariuszy włożonego w ruch krucjatowy. Juryści Filipa mieli satysfakcję w upokorzeniu niegdyś dumnych templariuszy. J. de Molay opisujac siebie podczas przesłuchania jako miles illitteratus et pauper, prosił się o patronat W. de Plaisians ${ }^{52}$.

Jak widać, czytanie książek sprzed 1895 r. nie jest tak szkodliwe, jak można by sądzić. Czy opisani przez H.Ch. Leę osobnicy „zdolni bezwzględni” po publikacji R. Fawtiera z 1941 r. zmienili się w królewskich służących, którzy „stali się bardziej królewscy niż sam król"53, a następnie, w interpretacji R.I. Moore’a z 1987 r., powrócili jako wzrastający $\mathrm{w}$ siłę literati? Niechaj ostatnie zdanie należy do W. de Plaisians, który rzekł, że „sam Bóg wybrał takich właśnie ministrów [królewskich] dla osiągnięcia zwycięstwa, nieszukajacych $\mathrm{w}$ tej sprawie niczego dla siebie. Chrystus bowiem odsunął od nich wszelka chciwość i próżna sławę"54.

$Z$ języka angielskiego przełożył

MARCIN MĘCINA*

51 Le Dossier..., s. 122-123.

52 Ibidem, s. 164-165.

53 R. F aw ti e r, op. cit., s. 182.

${ }^{54}$ Le Dossier..., s. 114-115.

* Uniwersytet Łódzki, Wydział Filozoficzno-Historyczny, Instytut Historii, Katedra Historii Sredniowiecznej. 